\title{
Erratum to: Oxidative stress and the genomic regulation of aldosterone-stimulated NHE1 activity in SHR renal proximal tubular cells
}

\author{
Vanda Pinto • Maria João Pinho • Ulrich Hopfer • \\ Pedro A. Jose • Patrício Soares-da-Silva
}

Published online: 2 August 2011

(C) Springer Science+Business Media, LLC. 2011

Erratum to: Mol Cell Biochem (2008) 310:191-201

DOI 10.1007/s11010-007-9680-6

In the original article, Fig. 3 was not displayed correctly. Everything else in the paper remains correct.

The online version of the original article can be found under doi:10.1007/s11010-007-9680-6.

V. Pinto $\cdot$ M. J. Pinho $\cdot$ P. Soares-da-Silva $(\bowtie)$

Faculty of Medicine, Institute of Pharmacology

and Therapeutics, Porto 4200, Portugal

e-mail: pss@med.up.pt

\section{U. Hopfer}

Department of Physiology and Biophysics, Case Western

Reserve School of Medicine, Cleveland, OH, USA

\section{P. A. Jose}

Department of Pediatrics, Georgetown University, Washington,

DC, USA
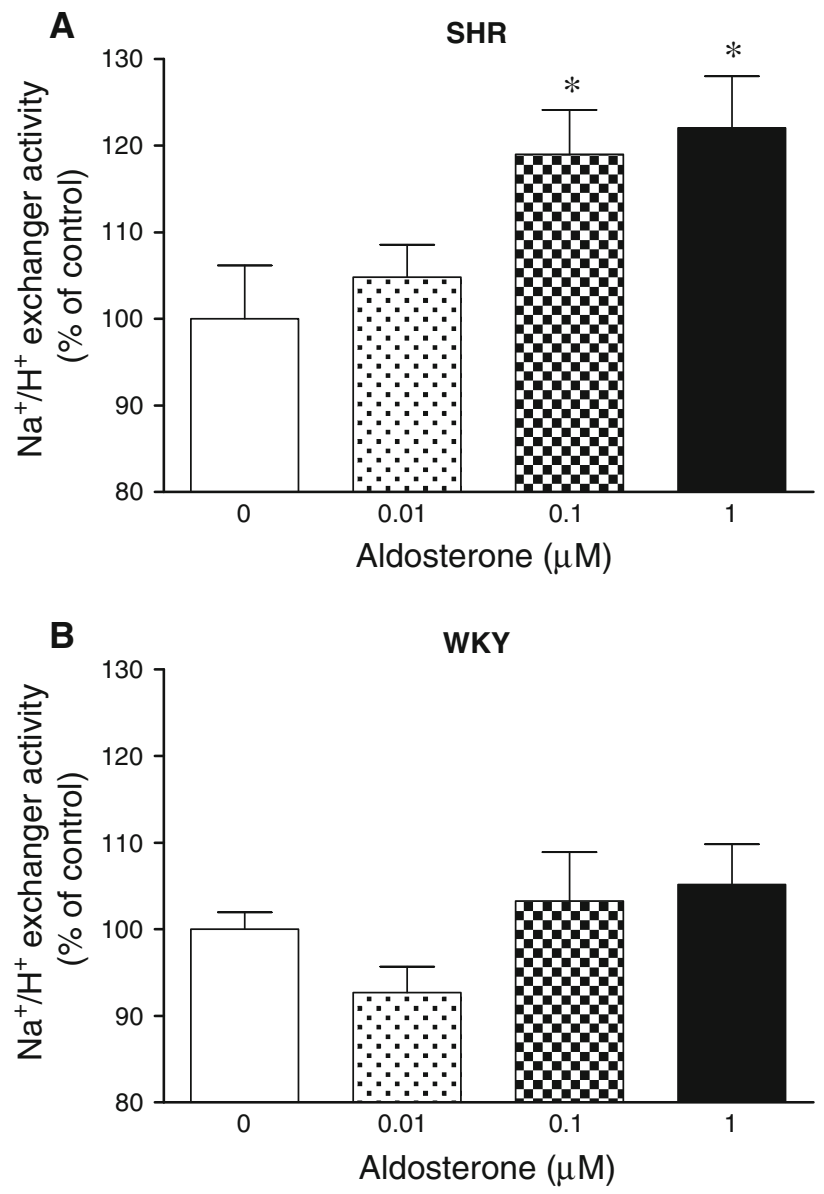

Fig. 3 Effect of aldosterone $(0.01,0.1$, and $1 \mu \mathrm{M})$ for $72 \mathrm{~h}$ on NHE activity in (a) SHR PTE cells and (b) WKY PTE cells. In WKY PTE cells, the $\mathrm{pH}_{\mathrm{i}}$ values in vehicle- and aldosterone-treated were, respectively, $7.51 \pm 0.01$ and $7.48 \pm 0.02$. In SHR PTE cells, the $\mathrm{pH}_{\mathrm{i}}$ values in vehicle- and aldosterone-treated were, respectively, $7.63 \pm 0.02$ and $7.66 \pm 0.03$. Each column represents the mean of 7-8 experiments per group; vertical lines indicate SEM. Significantly different from values for control $(* P<0.05)$ 